\title{
Forecasting the working capacity of personnel at the recruitment stage as a factor in ensuring the sustainable development of the enterprise
}

\author{
Alexander Stepus ${ }^{1, *}$, and Elmira Galyamova ${ }^{2}$ \\ ${ }^{1}$ LLC “Axion Corporation”, 426000, Maxim Gorky st., 90, Izhevsk, Russia \\ ${ }^{2}$ Udmurt State University, 426034, Universitetskaya st., 1/4, Izhevsk, Russia,
}

\begin{abstract}
A variant of minimizing personnel costs while maximizing their productivity and efficiency is proposed, by selecting the most efficient ones even when hiring. The article analyzes the influence of factors of personnel competitiveness in the modern labor economy on the efficiency of personnel. A system of factors and quantifiable parameters that affect performance is presented. Based on the analysis of the correlation and mathematical dependence of the factors, mathematical dependencies are determined that allow us to predict the efficiency of personnel when hiring. The obtained formulas for predicting performance in practice were tested and a conclusion was made about the possibility of its use in enterprises.
\end{abstract}

\section{Introduction}

The enterprise as an economic system embedded in the external environment requires a constant search for new solutions to ensure sustainable development. In the context of global threats to economic stability, the restrictive work formats associated with the spread of coronavirus infection, the impact of negative factors in the development of the world economy, it is necessary to correctly approach the formation of the enterprise's potential. To minimize risks and neutralize possible threats to the economic security of an economic entity, it is necessary to ensure the high quality of resources at the entrance. Special place in this process is occupied by the formation of human resources.

Sustainable development implies the continuous improvement of the key performance indicators of the enterprise, the growth of financial results by increasing the efficiency of resource use, reducing costs, including by increasing labor productivity and optimizing costs. As you know, the cost of maintaining staff occupies the largest share in the overall cost structure. In modern conditions, those enterprises that were able to reduce the cost of personnel, getting the maximum return from it, survive. Therefore, the issues of selecting the most promising employees from the point of view of labor efficiency are becoming particularly relevant.

If we do not consider the competencies on the basis of which the selection of candidates in the labor market is conducted, then we could assume that the greatest benefit will be brought by those potential employees who initially have a high working capacity, which

${ }^{*}$ Corresponding author: stepus19811@mail.ru 
means that they can achieve high labor results to a greater extent. The quantitative indicators of the evaluation of labor results include the labor productivity of production workers, the volume of sales in physical and value terms, the number of contracts concluded or documents processed. The indicators of the quality of the work performed could include the number of complaints, the percentage of defects, the cost of the unaccepted work. Also, when evaluating the efficiency of labor, it is necessary to take into account the loss of working time associated with absenteeism, lateness to work, long breaks during the labor process, and so on. For example, a factor such as compensation for working capacity due to the rest of the employee has an ambiguous effect on the working capacity. This aspect has been analyzed L.F. Magerya [1]. The guarantee and the main condition for the growth of labor productivity and working capacity, according to A. B. Kilin [2], is labor safety, which must also be taken into account in work. V. E. Dementyev [3] argues about the importance of assessing productivity, taking into account regional, local aspects, which is also no less important in the current crisis conditions.

In order to reduce the potential monetary losses associated with the labor activity of employees, reduce threats to personnel security, and minimize the cost of maintaining personnel, it is necessary to select such employees in the labor market who would have the necessary competencies and at the same time be as efficient and productive as possible. Predicting the efficiency of personnel when hiring will allow you to select from potential candidates only those who can bring the maximum benefit, which means that the company really needs them. The development of such a methodology is more relevant than ever right now. However, before implementing such a development, it is necessary to disclose the concept of personnel efficiency, determine the factors that have the greatest impact on it, and develop a methodology by which it is possible to predict the efficiency of personnel when hiring using correlation analysis methods.

\section{Methodology for predicting the efficiency of personnel}

Working capacity is most often considered as a potential (physiological and psychological) ability of an employee to effectively perform work for a given time. This concept should be distinguished from the concept of working capacity, which is interpreted as the ability to participate in work activities. The working capacity and working capacity of an employee determine its competitiveness. To study the factors of personnel competitiveness formation in the framework of this study, the works of a number of researchers were analyzed: B. M. Genkin, V. N. Bobkov, Yu. S. Kupriyanov, M. G. Mdinardadze, P. S. Mstislavsky [4], A. K. Gastev [5], A Mazin [6], T. V. Khlopov [7], P. A. Shutov [8], V. Zh. Dubrovsky, E. M. Ivanov, N. V. Chuprakov [9], I. B. Ipatova [10]. At least four different methods with a diverse set of factors and parameters were divided into groups and adapted to the author's classification presented in Table 1.

In addition to working capacity and ability to work, many authors distinguish among the factors of competitiveness such as: thesaurus and communication experience.

Thesaurus is a complex system of accumulation, storage, and multiplication of information, knowledge, and experience in the professional sphere. It is almost impossible to measure the value of knowledge and experience of an employee, since it constantly changes every second, but if we consider an enterprise, then the thesaurus can and should be evaluated as the accumulated experience of management.

All factors of competitiveness can be divided into objective (subject to precise determination) and subjective (depending on the preferences of the expert). In the present study, the most interesting are the objective factors that can be quantified and, through these quantitative determinants, reveal the mathematical dependence. This dependence would allow, knowing the initial factors, to evaluate and predict the performance of personnel, 
even at the stage of hiring them, and to select personnel who are inclined to increase their performance in the conditions provided by the enterprise.

Table 1. Classification of personnel competitiveness factors.

\begin{tabular}{|c|c|c|c|c|}
\hline & Operability & Work capacity & Thesaurus & $\begin{array}{c}\text { Communication } \\
\text { experience }\end{array}$ \\
\hline 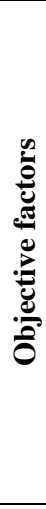 & $\begin{array}{l}\text { - productivity; } \\
\text { - gender; } \\
\text { - state of health; } \\
\text { - self discipline; } \\
\text { - resources of } \\
\text { working time; } \\
\text { - cost of labor, } \\
\text { wages }\end{array}$ & $\begin{array}{l}\text { - labor mobility } \\
\text { potential; } \\
\text { - age; } \\
\text { - educational level } \\
\text { (professional } \\
\text { training); } \\
\text { - qualification } \\
\text { level; } \\
\text { - work experience } \\
\text { (experience) }\end{array}$ & $\begin{array}{l}\text {-the number of } \\
\text { hours of study and } \\
\text { the achieved level of } \\
\text { education; } \\
\text {-the number of } \\
\text { hours of advanced } \\
\text { training; } \\
\text {-the quality level of } \\
\text { education; } \\
\text {-the number of } \\
\text { developed } \\
\text { rationalization } \\
\text { proposals and } \\
\text { inventions }\end{array}$ & $\begin{array}{l}\text { - employment in all } \\
\text { professions as } \\
\text { managerial personnel } \\
\text { associated with the } \\
\text { experience of } \\
\text { management and } \\
\text { participation in the } \\
\text { adoption of } \\
\text { organizational and } \\
\text { administrative } \\
\text { documents; } \\
\text { - family status; } \\
\text { - nationality; } \\
\text { - citizenship }\end{array}$ \\
\hline हैं & $\begin{array}{l}\text { - activity; } \\
\text { - endurance; } \\
\text { - physical } \\
\text { development; } \\
\text { - conditions of rest - } \\
\text { playing sports; } \\
\text { - personal physical } \\
\text { data; } \\
\text { - nutrition; } \\
\text { - quality of work } \\
\text { results }\end{array}$ & $\begin{array}{l}\text { - the degree of } \\
\text { readiness for } \\
\text { professional } \\
\text { mobility; } \\
\text { - the degree of } \\
\text { readiness for } \\
\text { professional and } \\
\text { qualification } \\
\text { growth; } \\
\text { - the cost of } \\
\text { improving the } \\
\text { quality of the } \\
\text { workforce }\end{array}$ & $\begin{array}{l}\text { - creativity; } \\
\text { - moral qualities; } \\
\text { - professionalism } \\
\text { (skills) }\end{array}$ & $\begin{array}{l}\text { - relationships in the } \\
\text { team; } \\
\text { - external data; } \\
\text { - connections and } \\
\text { acquaintances; } \\
\text { - socio-psychological } \\
\text { climate and } \\
\text { partnership; } \\
\text { - sociability; } \\
\text { - adaptation to the } \\
\text { place of residence } \\
\text { and work }\end{array}$ \\
\hline
\end{tabular}

For the purpose of the study, the list of factors considered was supplemented, taking into account the analysis of the rights and obligations of the employee and the employer, collective agreements and labor regulations, the existing social and labor relations in the field of labor at a particular industrial enterprise.

The efficiency factor was singled out as the primary one. In practice, it is usually presented in the form of a percentage of compliance with the norms. In this study, the efficiency coefficient is considered, calculated as the ratio of the normalized and actually spent time according to timekeeping observation.

\section{Analysis of tools for market forecasting of employee performance and approbation of research results}

By conducting timekeeping observations and actually identifying employees with the minimum duration of work, the most efficient staff was selected. Thus, the primary criteria for assessing their correlation with performance were formed, which are shown in all the criteria of personnel competitiveness, in particular: 1) working capacity (the ratio of normalized and actually worked time by timekeeping); 2) the variety of professions, measured by the sum of labor units (trades) by profession, taking into account qualifications; 3) marital status (4 - married, 3 - widowed, 2 - unmarried, 1 - divorced); 4) 
the number of children; 5) work experience in years; 6) the number of violations of discipline(labor, technological); 7) age; 8) the level of remuneration; 9) the number of hours of study at extension courses, training courses, colleges, and universities.

Table 2. Analysis of correlation of factors of personnel efficiency.

\begin{tabular}{|l|c|}
\hline \multirow{2}{*}{\multicolumn{1}{|c|}{ Indicators }} & Working capacity \\
\cline { 2 - 2 } & y1- (avrg. hours / ind. hours) \\
\hline x1- marital status & $-0,032$ \\
\hline x2 - quantity of children & 0,423 \\
\hline x3 - experience, number of years & 0,82 \\
\hline x4 - level education & $-0,072$ \\
\hline x5 - years of study & 0,237 \\
\hline x6 - overtime hours & 0,29 \\
\hline x7 - quantity of discipline violations & $-0,925$ \\
\hline x8 - age & 0,444 \\
\hline x9 - quantity of rewards & 0,466 \\
\hline x10 - wage & 0,45 \\
\hline x11 - variety of professions, & 0,432 \\
\hline x12 - number of conflicts & $-0,045$ \\
\hline x13 - sick leave, hours. & $-0,065$ \\
\hline
\end{tabular}

As a result, formulas for predicting performance were developed (Table 3), they are based on the influence of the two most significant factors - the length of service and the number of violations of labor discipline. In the group with a large number of violations of discipline, the most efficient employees were identified, and in the group with minimal violations of discipline - the most efficient employees with a $\mathrm{Cwc}>2.5$.

Table 3. Analysis of market forecasting tools for working capacity.

\begin{tabular}{|c|c|c|c|c|c|c|c|c|c|}
\hline \multirow{4}{*}{$\begin{array}{c}\text { Experience, } \\
\mathbf{E}\end{array}$} & \multicolumn{9}{|c|}{ Number of discipline violations, D } \\
\hline & 30 & 25 & 20 & 15 & 10 & 5 & 3 & 1 & 0 \\
\hline & \multicolumn{5}{|c|}{$\begin{array}{l}\text { Formula } 1 \text { for determining of working } \\
\text { capacity }(\mathrm{D}>5)\end{array}$} & \multicolumn{4}{|c|}{$\begin{array}{l}\text { Formula } 2 \text { for determining of working } \\
\text { capacity (D from } 0 \text { to } 5 \text { ) }\end{array}$} \\
\hline & \multicolumn{5}{|c|}{$\begin{array}{c}\mathrm{Cwc}=-0,886005+0,21979 \cdot \mathrm{D}-0,006747 \cdot \mathrm{D}^{2} \\
+1,0140104 \cdot \mathrm{D}-0,025386 * \mathrm{E}^{2}-0,1222832 \cdot \mathrm{D} \cdot \mathrm{E} \\
+0,00335516 \cdot \mathrm{D} \cdot \mathrm{E}^{2}+0,0033865 \cdot \mathrm{E} \cdot \mathrm{D}^{2}- \\
0,000097 \cdot \mathrm{D}^{2} \cdot \mathrm{E}^{2}\end{array}$} & \multicolumn{4}{|c|}{$\begin{array}{c}\mathrm{Kwc}=0,91363-0,059866 \cdot \mathrm{D}-0,022748 \cdot \mathrm{DI} \\
+0,09122 \cdot \mathrm{E}+0,00027 * \mathrm{EI}+0,150152 \cdot \mathrm{D} \cdot \mathrm{E}- \\
0,0061807 \cdot \mathrm{D} \cdot \mathrm{EI}-0,012966 \cdot \mathrm{E} \cdot \mathrm{DI}+ \\
0,0007513 \cdot \mathrm{DI} \cdot \mathrm{EI} \\
\end{array}$} \\
\hline 1 & 0,0167 & 0,4632 & 0,7369 & 0,8376 & 0,7655 & 0,5516 & 0,9428 & 1,0543 & 1,0051 \\
\hline 2 & 0,3740 & 0,5303 & 0,6686 & 0,7887 & 0,8907 & 1,0339 & 1,3332 & 1,2672 & 1,0972 \\
\hline 3 & 0,7072 & 0,5932 & 0,6061 & 0,746 & 1,0129 & 1,4924 & 1,7007 & 1,4698 & 1,1897 \\
\hline 4 & 1,0164 & 0,6517 & 0,5495 & 0,7095 & 1,1320 & 1,9273 & 2,0451 & 1,6621 & 1,2828 \\
\hline 5 & 1,3014 & 0,7060 & 0,4987 & 0,6793 & 1,2480 & 2,3385 & 2,3665 & 1,8441 & 1,3765 \\
\hline 7 & 1,7994 & 0,8019 & 0,4146 & 0,6375 & 1,4708 & 3,0897 & 2,9402 & 2,1770 & 1,5654 \\
\hline 10 & 2,3659 & 0,9136 & 0,3322 & 0,6217 & 1,7820 & 4,0388 & 3,6281 & 2,5991 & 1,8528 \\
\hline 15 & \begin{tabular}{|l|}
2,8288 \\
\end{tabular} & 1,0146 & 0,3116 & 0,7198 & 2,2394 & 5,1466 & 4,3142 & 3,0962 & 2,3427 \\
\hline 20 & 2,6902 & 1,0089 & 0,4368 & 0,9738 & 2,6200 & \begin{tabular}{|l|}
5,6618 \\
\end{tabular} & 4,4248 & 3,3354 & 2,8460 \\
\hline 25 & 1,9500 & 0,8967 & 0,7079 & 1,3836 & 2,9239 & 5,5845 & 3,9599 & 3,3165 & 3,3629 \\
\hline 30 & 0,6082 & 0,6779 & 1,1249 & 1,9493 & 3,1511 & 4,9146 & 2,9194 & $\mathbf{3 , 0 3 9 7}$ & $\mathbf{3 , 8 9 3 2}$ \\
\hline 35 & - & 0,3524 & 1,6877 & 2,6707 & 3,3015 & \begin{tabular}{|l|}
3,6522 \\
\end{tabular} & 1,3034 & 2,5050 & 4,4371 \\
\hline 40 & - & - & 2,3964 & 3,548 & $\mathbf{3 , 3 7 5 3}$ & 1,7972 & - & 1,7122 & 4,9944 \\
\hline 45 & - & - & & 4,5811 & 3,3723 & \begin{tabular}{|l|} 
\\
\end{tabular} & - & 0,6615 & 5,5653 \\
\hline
\end{tabular}


Interesting is the revealed pattern of proportionate growth of working capacity with age in the most disciplined personnel, in contrast to the maximum return during the period of experience from 10 to 30 years in less disciplined employees. This is due to the abrupt working capacity of the body of the employee who violates the work schedule, and the constant growth of the working capacity of employees who have an unchanged schedule and comply with it. At the same time, the maximum return from less disciplined workers is observed in the average period of work from 10 to 30 years (age 28-48 years), in contrast to the most disciplined workers, who achieve the maximum return on their work in the preretirement age. Some freedom in the observance of discipline also contributes to a faster set of the necessary performance capabilities. So those who have 1 disciplinary penalty from 1 to 25 years of experience, have greater efficiency than disciplined personnel. This is due to the necessity to overstep the boundaries of the technological discipline sometimes and make a detail at your own discretion and it often turns to be even faster than using technology in compliance with all quality requirements. Such workers may have one violation of labor discipline, as well as a technological one, due to the creative need for internal freedom, which often reflected in this form. The least efficient workers are those who often violate discipline. They have maximum working capacity only during certain periods of labor activity.

Based on these developments, recommendations to the personnel management service, which conducted a practical experiment were made. At the initial selection of employees, the forecast level of efficiency was calculated based on the length of service and the number of violations of discipline. Subsequently, timekeeping measurements were carried out and minor deviations of the forecast values from the actual ones were revealed. This allowed us to supplement the formulas for predicting performance. The deviation analysis is shown in Table 4.

Table 4. Approbation of formulas for predicting working capacity in practice.

\begin{tabular}{|c|c|c|c|c|c|}
\hline \multicolumn{2}{|c|}{$\begin{array}{c}\text { Information from } \\
\text { employment history when } \\
\text { hiring on the labor } \\
\text { market } \\
\end{array}$} & \multicolumn{2}{|c|}{ Forecasting for working capacity } & \multicolumn{2}{|c|}{$\begin{array}{l}\text { Checking after admission } \\
\text { according to timing } \\
\text { observations and deviations } \\
\text { from the predicted level }\end{array}$} \\
\hline $\begin{array}{l}\text { Work } \\
\text { experience, } \\
\text { E }\end{array}$ & $\begin{array}{l}\text { Number of } \\
\text { discipline } \\
\text { violations, D }\end{array}$ & Formulas & Кр & $\begin{array}{l}\text { Working } \\
\text { capacity factor } \\
\text { for timing } \\
\text { measurements }\end{array}$ & \begin{tabular}{|c|}
$\begin{array}{c}\text { Deviation from } \\
\text { predicted values } \\
\text { in } \%\end{array}$ \\
\end{tabular} \\
\hline 1,51 & 25 & \multirow{5}{*}{$\begin{array}{c}\mathrm{Kp}=-0,886005+0,21979 \cdot \mathrm{D}- \\
0,006747 \cdot \mathrm{D}^{2}+1,0140104 \cdot \mathrm{D}- \\
0,025386 * \mathrm{E}^{2}-0,1222832 \cdot \mathrm{D} \cdot \mathrm{E} \\
+0,00335516 \cdot \mathrm{D} \cdot \mathrm{E}^{2}+ \\
0,0033865 \cdot \mathrm{E} \cdot \mathrm{D}^{2}- \\
0,000097 \cdot \mathrm{D}^{2} \cdot \mathrm{E}^{2}\end{array}$} & 0,5 & 0,445 & $-12 \%$ \\
\hline 0,82 & 23 & & 0,594567812 & 0,655 & $9 \%$ \\
\hline 2,81 & 23 & & 0,583925898 & 0,684 & $15 \%$ \\
\hline 1,32 & 19 & & 0,745222588 & 0,823 & $9 \%$ \\
\hline 3,00 & 11 & & 0,949548895 & 0,802 & $-18 \%$ \\
\hline 2,27 & 5 & \multirow{11}{*}{$\begin{array}{c}\mathrm{Kp}=0,91363-0,059866 \cdot \mathrm{D}- \\
0,022748 \cdot \mathrm{D}^{2}+0,09122 \cdot \mathrm{E}+ \\
0,00027 * \mathrm{E}^{2}+0,150152 \cdot \mathrm{D} \cdot \mathrm{E}- \\
0,0061807 \cdot \mathrm{D} \cdot \mathrm{E}^{2}- \\
0,012966 \cdot \mathrm{E} \cdot \mathrm{D}^{2+} \\
0,0007513 \cdot \mathrm{D}^{2} \cdot \mathrm{E}^{2}\end{array}$} & 1,1596256825 & 1,1615 & $0 \%$ \\
\hline 2,75 & 5 & & 1,38 & 1,378 & $0 \%$ \\
\hline 32,32 & 5 & & 4,4022135366 & 4,4 & $0 \%$ \\
\hline 1,92 & 3 & & 1,3038245001 & 1,375 & $5 \%$ \\
\hline 2,86 & 3 & & 1,6518442528 & 1,399 & $-18 \%$ \\
\hline 3,30 & 3 & & 1,8071094461 & 1,98 & $9 \%$ \\
\hline 29,30 & 3 & & 3,0991965278 & 3,1 & $0 \%$ \\
\hline 0,82 & 0 & & 0,9882226999 & 1 & $1 \%$ \\
\hline 18,18 & 0 & & 2,6617231518 & 2,714 & $2 \%$ \\
\hline 24,60 & 0 & & 3,3208920443 & 3,243 & $-2 \%$ \\
\hline 29,3 & 0 & & 3,8181683000 & 3,863 & $1 \%$ \\
\hline
\end{tabular}

By the method of expert assessments, it was concluded that this method can prove itself in the management practice of developing and making decisions about hiring potential 
employees, and has a high practical utility.

Many works of a group of scientists under the leadership of O. M. Perminova [11-15] are devoted to this problem.

\section{Conclusions}

The conducted research allows us to draw some general conclusions:

1. The sustainable development of any organization as an economic system implies the continuous improvement of the key performance indicators of the enterprise, by increasing the efficiency of the use of labor resources and reducing the cost of maintaining staff.

2. To reduce the losses associated with the efficiency of labor activity of employees, a method of selecting employees at the «entrance», at the recruitment stage, on the basis of maximum efficiency is necessary. Such a methodology would make it possible to predict the efficiency of personnel at enterprises, using a number of evaluation criteria.

3. To assess the performance, it is advisable to compare the time spent (normalized and actual).

As a result of the research, formulas for predicting the efficiency of personnel in the labor market were developed, and their testing was carried out. The received data are issued as recommendations to the HR management service.

\section{References}

1. L. F. Magerya, Journal "Mining Information and Analytical Bulletin, 3, (2006)

2. A. B. Kilin, Coal Magazine, 3 (2018)

3. V. E. Dementyev, Regional Economy, 15(1) (2019)

4. V. N. Bobkov, Yu. S. Kupriyanov, M. G. Mdinaradze, P. S. Mstislavsky, The standard of living of the population of the regions of Russia, 5, 22 (2002)

5. A. K. Gastev, Labor Installations (1973)

6. A. Mazin, Man and Labor, 5, 50 (2005)

7. T. V. Khlopova, Labor law, 9, 82 (2002)

8. P. A. Shutova, Economic synergetics. Innovative development of Russia: collection of scientific papers, 150 (2007)

9. V. Zh. Dubrovsky, E. M. Ivanova, N. V. Chuprakova, Economy of Region, 16(3) (2020)

10. I. B. Ipatova, Applied Econometrics, Ewepa, 39(3) (2015)

11. O. M. Perminova, G. A. Lobanova, Acta Logistica, 1(5) (2018)

12. O. M. Perminova, G. A. Lobanova, R.V. Faizullin, Acta Logistica, 2 (2019)

13. V. I. Goldfarb, E. G. Krylov, O. M. Perminova, N. A. Barmina, L. Vasiliev, Advanced Gear Engineering. "Mechanisms and Machine Science" (2018)

14. G. E. Kalinkina, N. G. Sokolova, D. M. Gadzhikurbanov, O. M. Perminova, Vibroengineering Procedia. 23, Modeling, Identification and Fault Detection in Oil and Gas Equipment and Infrastructures. "23rd International Conference on Vibroengineering" (2016)

15. K.V. Pavlov, O.M. Perminova, V.E. Lyalin, G.E. Kalinkina, T.A. Berkutova, Vibroengineering Procedia. 24, Theories, Technologies and Applications in Vibration Engineering. "24th International Conference on Vibroengineering" (2016) 